\title{
Soybean natural cross-pollination rates under field conditions
}

\author{
Jeffery D. RAY ${ }^{1, *}$, Thomas C. KILEN ${ }^{1}$, Craig A. ABEL ${ }^{2}$, and Robert L. PARIS ${ }^{1}$ \\ ${ }^{1}$ USDA-ARS, Crop Genetics and Production Research Unit, Stoneville, MS 38776, USA \\ ${ }^{2}$ USDA-ARS, Southern Insect Management Research Unit, Stoneville, MS 38776, USA
}

\begin{abstract}
Recent concerns regarding within-crop transgene flow stimulated this research to update natural crosspollination rates in conventional sowings of modern soybean [Glycine max (L.) Merr.] in the Mississippi Delta. Two experiments were conducted in 2001 and 2002 using two soybean cultivars, "Pace" (white-flowered) and "DP3588" (purple-flowered), selected for their equivalent flowering dates. The experiments utilized the dominance of purple flower color over white flower color to identify natural cross-pollinations. In the first experiment, 12 rows of Pace (white-flowered) flanked on each side by four rows of DP3588 (purple flowered) were sown on 10 May 2001. Seed were harvested by row from each of the Pace rows and examined for natural cross-pollinations in the next generation. In total, 73512 potential hybrid plants were examined and natural cross-pollination rates ranged from $0.41 \%$ at $0.9 \mathrm{~m}$ from the pollen source to $0.03 \%$ at $5.4 \mathrm{~m}$ from the pollen source. These values were consistent with values previously reported in the literature. In the second experiment, seed of Pace and DP3588 were alternately sown $15.2 \mathrm{~cm}$ apart within a row in 2001. At maturity, 167 Pace plants (white-flowered) were harvested and a total of 19151 progeny were evaluated for natural cross-pollinations in the next generation. The progeny of $56(33.5 \%)$ of the 167 parent plants showed no evidence of natural crosspollination. The progeny of the remaining 111 plants exhibited natural cross-pollination rates ranging from 0.65 to $6.32 \%$ and averaged $1.8 \%$. The maximum rates reported here are considerably higher than most previously reported rates. The results of these two experiments highlight the potential for within-crop transgene flow in soybean.
\end{abstract}

Key words: natural cross pollination / soybean / gene flow

\section{INTRODUCTION}

Since the introduction of glyphosate-resistant (GR) soybean in 1996, the United States hectarage sown to transgenic soybean cultivars has steadily increased. In the 2002 season, GR cultivars accounted for approximately $75 \%$ of the soybean hectarage sown in the USA (NASS, 2002). While GR soybean accounts for virtually all soybean transgenics grown commercially, there is a wide range of experimental soybean transgenics being evaluated for various purposes. For example, soybean transformants range from a line transformed with a Brazil nut tree [Bertholletia excelsa (Castanheira) Humb. and Bonpl.] gene (Streit et al., 2001; Townsend and Thomas, 1994 ; 1996) to lines transformed to express virus coat proteins (Reddy et al., 2001; Steinlage et al., 2002; Wang et al., 2001), as well as soybean lines incorporating a
Bacillus thuringiensis crylAc transgene (Walker et al., 2002). While many of these transformants may have limited commercial potential, it is likely that future cultivars with various transgenes and transgene combinations will be commercially available. As more transgenic cultivars become available, the contamination of conventional cultivars with transgenes and the unintended combination of transgenes through natural crossing will become increasingly probable. In addition to within-crop transgene flow, the likelihood of transgene flow to wild relatives will also increase. Gene flow from domesticated plants into wild relatives is well documented in other species (for review see Ellstrand et al., 1999). Given the current litigious environment and other concerns associated with unintended hybridization,

\footnotetext{
* Corresponding author:

Fax: (1)662-686-5218; e-mail: jray@ars.usda.gov

Mention of a trademark or proprietary product does not constitute a guarantee or warranty of the product by the U.S. Department of Agriculture and does not imply approval or the exclusion of other products that may also be suitable.
} 
it is necessary to update the estimation of natural crosspollination rates in modern soybean.

Weber and Hanson (1961) stated that natural crosspollination rates in soybean grown in adjacent rows was less than $0.5 \%$ and about $1 \%$ for plants grown in close contact. However, reported values of natural cross-pollination rates vary greatly. Woodworth (1922) observed natural cross-pollination rates for soybean grown in adjacent rows of about $0.04 \%$, whereas Ahrent and Caviness (1994) observed rates as high as $2.5 \%$. Other reported rates have generally been less than $0.5 \%$ between rows (Garber and Odland, 1926; Woodworth, 1932). Natural crossing rates for relatively close, equally spaced plants $(30 \mathrm{~cm})$ have been reported as high as 4.52\% (Gumisiriza and Rubaihayo, 1978).

Weber and Fehr (1967) stated that natural crosspollination in soybean is dependent upon the distance between plants, the genotypes involved, the environment, and the insects present. However, it is likely that insect populations and activity have the biggest impact on natural cross-pollination rates. Common cultural practices for soybean production in the lower Mississippi river alluvial flood plain rarely involve insecticide application before anthesis. Consequently, the potential exists for natural cross-pollination. Herein, we report the results of two experiments examining rates of natural cross-pollination in soybeans grown in the Mississippi Delta. Both experiments utilized the dominance relationship of purple flowers over white flowers in soybean (Woodworth, 1923). When a white-flowered soybean is pollinated by a purple-flowered soybean, plants produced by that pollination will have purple flowers. This relationship has been used previously to observe rates of natural cross-pollination in soybean (Ahrent and Caviness, 1994; Caviness, 1966).

\section{RESULTS AND DISCUSSION}

In the first experiment, a total of 73512 plants ( 12 rows $\times$ 6126 plants.row $^{-1}$ ) were observed in 2002 for evidence of natural cross-pollination that may have occurred in 2001. Rates of natural cross-pollination were calculated based on the frequency of purple flowers in an expected pure, white-flowered background. Figure 1 shows the number of hybrid plants and the percentage natural cross-pollination for each row. The percentage natural cross-pollination decreased with distance from the purple-flowered rows. Rates of natural cross-pollination ranged from 0.41 and $0.29 \%$ in rows directly bordering (0.9 $\mathrm{m}$ spacing) the pollen source (purple-flowered plants) to 0.03 and $0.05 \%$ in the middle rows equidistant

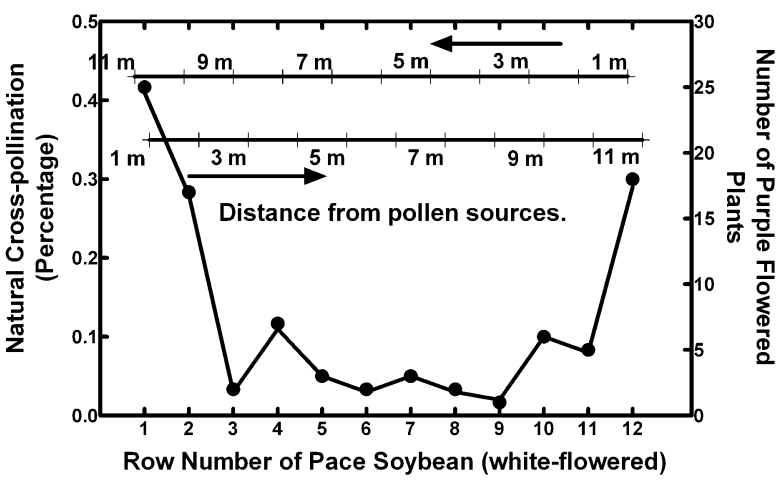

Figure 1. Natural crossing percentage (left y-axis) and the actual number of purple-flowered plants detected (right $y$-axis) in the progeny of each row from Experiment 1. Rows are spaced $0.9 \mathrm{~m}$ apart. In the 2001 planting, the 12 rows of the Pace soybean cultivar (white-flowered) indicated in the figure were flanked on either side by four rows of DP3588 (purpleflowered) which served as the pollen source. Approximately 6126 progeny from each of the 12 rows of Pace soybean were screened in 2002 to detect cross-pollination events.

(5.4 m) from the pollen source (Fig. 1). These results are consistent with Caviness (1966) in which maximum natural cross-pollination rates of $0.44 \%$ were observed for soybean grown in adjacent rows spaced $0.9 \mathrm{~m}$ apart.

In the first experiment, rows one and two of the whiteflowered plants had a greater cross-pollination rate than did the two corresponding rows on the other side of the experimental area (rows 11 and 12). This may be a result of the way in which the experiment was arranged in the field. The four rows of DP3588 bordering row one of Pace marked the northern edge of the field. Beyond these rows was a wide field road. On the other side of the experimental area, beyond the four rows of DP3588, was a continuous field of soybean for at least $36 \mathrm{~m}$. It may be that there was increased insect activity on the more open side of the experimental area.

Most cross-pollination in soybean is likely facilitated by insects (Erickson et al., 1978; Rust et al., 1980). Insect collections were made biweekly over four weeks during the flowering period for each genotype in the first experiment of 2001. Between the two genotypes, there were no significant differences $(P>0.05)$ in the number of either pest or beneficial insects collected. Over the 4-week measuring period, a total of 529 pest insects representing 11 families and 177 beneficial insects representing 9 families were collected (Tab. 1). Rust et al. (1980) reported 29 species of insect pollinators foraging soybeans grown in three regions of the United States. Curiously, no insect pollinator species were collected in 
Soybean natural cross-pollination rates

Table 1. The number of pest and beneficial insects identified from biweekly sampling over a four week period during flowering. Insects are arranged by family.

\begin{tabular}{|c|c|c|c|c|c|}
\hline \multicolumn{3}{|c|}{ Pest Families } & & \multicolumn{2}{|c|}{ Beneficial Families } \\
\hline & Family & Insects & & Family & Insects \\
\hline 1 & Acrididae & 11 & 1 & Anthocoridae & 12 \\
\hline 2 & Arctiidae & 1 & 2 & ${ }^{1}$ Braconidae & 6 \\
\hline 3 & Cicadellidae & 76 & 3 & ${ }^{1}$ Chloropidae & 6 \\
\hline 4 & Chrysomelidae & 277 & 4 & ${ }^{1}$ Coccinellidae & 10 \\
\hline 5 & Cydnidae & 1 & 5 & ${ }^{1}$ Chrysopidae & 2 \\
\hline 6 & Elateridae & 3 & 6 & ${ }^{1}$ Ichneumonidae & 1 \\
\hline 7 & Membracidae & 46 & 7 & Nabidae & 34 \\
\hline 8 & Miridae & 21 & 8 & Lygaeidae & 55 \\
\hline 9 & Noctuidae & 13 & 9 & ${ }^{1}$ Syrphidae & 51 \\
\hline 10 & Pentatomidae & 43 & & & \\
\hline 11 & Thripidae & 37 & & & \\
\hline & Total & 529 & & Total & 177 \\
\hline
\end{tabular}

\footnotetext{
${ }^{1}$ Known to visit floral nectaries, however, all insects listed may potentially visit flowers for food.
}

this study. However, some adult insects, especially parasitoids, are noted for their use of nectar as an energy source (Kopvillem, 1960; Van Emden, 1963). Ninetytwo percent $(n=706)$ of the insects sampled in this study were adults with $10 \%$ of these being parasitoids. While visiting soybean flowers for nectar, these insects could have transferred pollen grains between the purple- and white-flowered soybean cultivars.

In the second experiment, seed were sown in 2001 such that purple- and white-flowered plants were alternated and spaced $15.2 \mathrm{~cm}$ apart within the row. In 2001, 167 white-flowered plants were harvested and their progeny sown in 2002 (one row per harvested plant). Each row was screened to identify purple-flowered plants. In total, across all rows, 19151 progeny of the 167 plants harvested in 2001 were screened for flower color in the second experiment. Figure 2 shows the frequency distribution (histogram) of the natural crosspollination rates based on purple flower color observed in the 167 plants evaluated. The progeny of only $56(33.5 \%)$ plants showed no evidence of crosspollination (all white-flowered). The progeny of the remaining 111 plants exhibited natural cross-pollination rates ranging from 0.65 to $6.32 \%$ and averaged $1.8 \%$.
There was no correlation between the number of progeny in a row and the rate of cross-pollination $\left(\mathrm{r}^{2}=0.025\right)$. Cutler (1934) alternated five sets of cultivars differing in

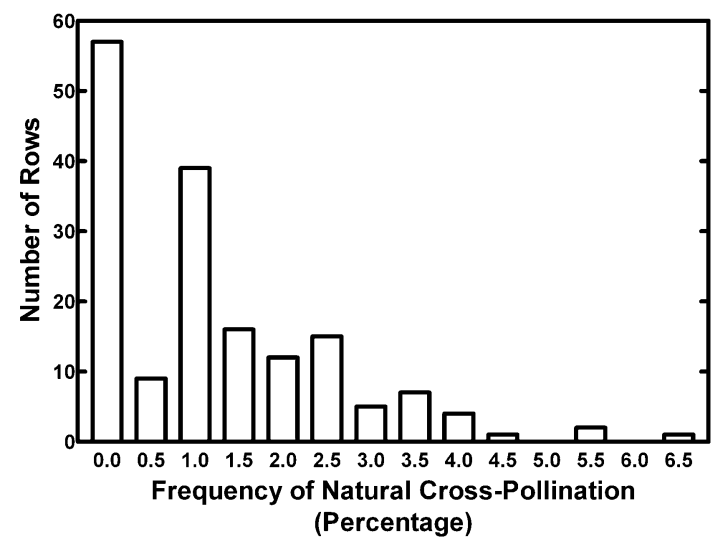

Figure 2. Histogram from Experiment 2 indicating the frequency of natural cross-pollination detected in 2002 from progeny of Pace (white-flowered) plants grown in alternating hills spaced $15.2 \mathrm{~cm}$ apart with "DP3588" (purpled-flowered) plants in 2001. Each row is the entire progeny of a single Pace plant from the 2001 sowing. Only 56 rows showed no detectable cross- pollination event. 
pubescence color at spacings of 5 to $7.5 \mathrm{~cm}$ within a row and $0.76 \mathrm{~m}$ between rows and reported natural crosspollination rates of from 0.79 to $2.43 \%$. However, the values Cutler (1934) reported seem to be averages across all plants within a cultivar set. In our study, we observed natural cross-pollination rates as high as $6.32 \%$ for individual plants spaced $15.2 \mathrm{~cm}$ apart.

Rates of natural cross-pollination based on the number of purple-flowered plants observed ranged from $0.41 \%$ in rows spaced $0.9 \mathrm{~m}$ apart to a maximum of $6.32 \%$ for plants spaced $15.2 \mathrm{~cm}$ apart. There is no evidence to indicate a unidirectional transfer of pollen and there was most likely a transfer of pollen from whiteflowered plants to purple-flowered plants. However, since the white color expression would have been masked by the dominance of the purple flower color, no attempt was made to measure this transfer. Actual crosspollination rates are likely higher than those reported here as there was likely pollen transfers among the whiteflowered plants and among the purple-flowered plants, neither of which could be detected by the methodology employed in this study.

This study and others clearly demonstrated the potential for natural cross-pollination in cultivated soybean (G. max). Ellstrand (2001) highlighted the potential of within-crop gene flow in addition to crop-toweed and crop-to-wild gene flow. In soybean, withincrop transgene flow may lead to unintended transgene combinations. Additionally, escapes of transgenes or transgene combinations into the natural environment may be potentially important in the southeastern United States where special reseeding soybean cultivars such as "Quail Haven" are sown as feed for upland game birds. It is conceivable that transgenes could flow from production fields to reseeding varieties intended for wild game feed. In other parts of the world, there is the potential for transgene flow from production fields to wild relatives of soybean. Fujita et al. (1997) examined four wild soybean (G. soja) populations in Japan and found natural crosspollination rates ranging from 9.3 to $19 \%$, considerably higher than those reported for G. max. Although natural cross-pollination rates between $G$. max and $G$. soja have not been determined, under the right circumstances, the potential may exist for natural interspecific crosspollination to occur. However, given the complex circumstances for natural cross-pollination to take place (distance from the pollen source, environment, insects present and their activity, as well as flowering synchronization), the probability of natural crosspollination between species may be low. Nonetheless, given the world-wide production of soybean, it is likely

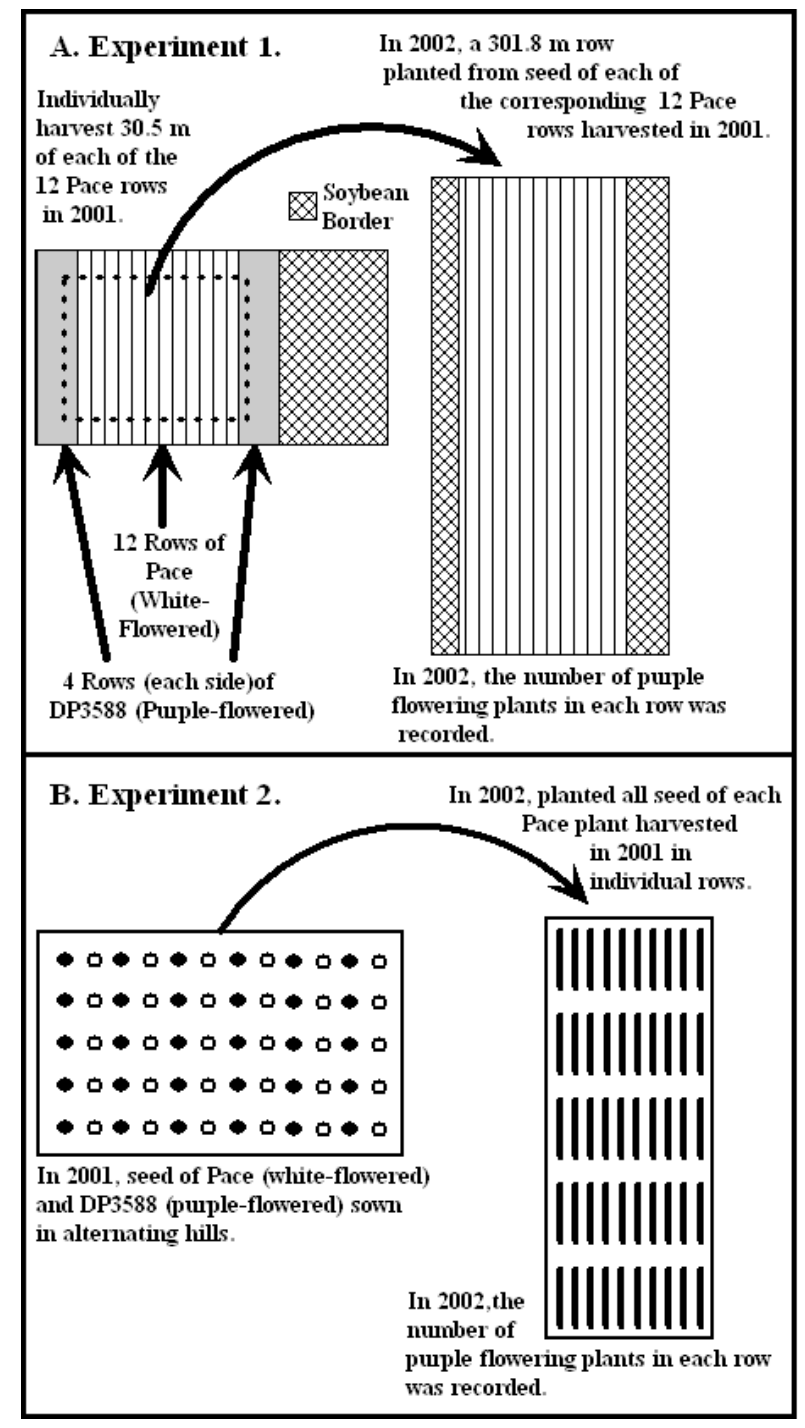

Figure 3. Diagrammatic representation of the field layout for the two experiments. In both experiments, cross-pollination occurred in 2001 and cross-pollination rates were determined by analyzing progeny in 2002 .

to occur. Whether natural cross-pollination leads to within-crop gene flow or to interspecific gene flow, the commercialization of transgenic soybean should be closely monitored based on the nature of the transgenes involved and their potential impact in the natural environment.

\section{MATERIALS AND METHODS}

Two Maturity Group V cultivars ("DP3588”, Delta and Pine Land Co., Scott, MS, and "Pace"; Hartwig et al., 
1998) with similar flowering dates were used in this study. "DP3588" (Shannon and Collins, 2001) has purple flowers and tawny pubescence whereas Pace has white flowers and gray pubescence. In the first experiment (Fig. 3A), 20 rows, approximately $45 \mathrm{~m}$ in length and spaced $0.9 \mathrm{~m}$ apart were sown on 10 May 2001. The in-row spacing was approximately $5 \mathrm{~cm}$. The first four rows and the last four rows were sown to "DP3588" (purple-flowered). The middle 12 rows were sown to Pace (white-flowered). "DP3588" began flowering (R1; Fehr and Caviness, 1977) on 26 June and Pace reached $\mathrm{R} 1$ on 28 June. All Pace rows were rogued twice at flowering to eliminate any plants with purple flowers. Rows were rogued again at maturity to remove any plants with off color pubescence. At maturity, $30.5 \mathrm{~m}$ of each of the Pace rows were individually harvested with a plot combine (Almaco, SPC-40, Nevada, IA).

Over a 4-week period during flowering, insect populations were sampled twice a week for each soybean genotype. For each sample, insects were collected by moving the opening of a standard sweep net $(0.38 \mathrm{~m}$ diameter) 25 times through the soybean foliage, upward through the main stem terminals, alternately from side to side, as the sampler walked down the length of the row. The contents of the sweep net were shaken into a plastic bag and taken into the laboratory where the insects were classified to family and quantified. All samples were collected in the morning between 800 and $1000 \mathrm{~h}$.

On 8 May 2002, twelve $301.8 \mathrm{~m}$-long rows were sown using seed from each of the 12 Pace rows harvested in 2001 (Fig. 3A). The rows were ordered as they occurred in the 2001 sowing (i.e. row one in 2002 was derived from row one in 2001, row two in 2002 was derived from row two in 2001, etc.). As in 2001, the row spacing was $0.9 \mathrm{~m}$. Stand counts were conducted after flowering to provide an estimate of the plant density. The field was divided into four quarters with each quarter treated as a replication for the purpose of estimating plant density. The number of plants in a $2.4 \mathrm{~m}$ portion of each of the 12 rows in each quarter (rep) was counted ( 4 quarters $\times 12$ rows $=48$ counts). There were no significant differences $(P>0.05)$ in the number of plants among rows and therefore the average plant density over all rows was calculated as $20.3( \pm 0.35)$ plants.meter $^{-1}$ of row. Each row was calculated to have 6126 plants (20.3 plants.meter ${ }^{-1}$.row $\times 301.8 \mathrm{~m} \cdot$ row $^{-1}$.length). At full bloom each of the 12 rows of Pace (white-flowered) was checked twice to identify the number of purple-flowered plants. At each evaluation, purple flowered plants were eliminated from the row.
In the second experiment (Fig. 3B), seed of Pace and DP3588 were sown by hand in alternating hills spaced $15.2 \mathrm{~cm}$ apart. The hills were organized in 10,6.1 m-long rows spaced $0.9 \mathrm{~m}$ apart. The seed were sown on 10 May 2001; however, because of a poor stand, it was resown on 29 May in a different area of the same field. At approximately the first vegetative stage (V1; Fehr and Caviness, 1977), plants were thinned to one plant per hill. Near the end of the flowering period, all purple-flowered plants were eliminated from the experiment. At maturity, 167 white-flowered plants were harvested and threshed individually using a single plant thresher. From each of these 167 plants, a single $6.1 \mathrm{~m}$-long row was sown on 8 May 2002 (Fig. 3B). Each row contained all the seed produced from the respective individual plant from 2001. Thus, the plant density of individual rows varied greatly (41 to 167 plants.row ${ }^{-1}$ ). The number of plants in each row was counted shortly after flowering. During full bloom, each of the 167 rows was screened twice, and the number of plants with purple flowers was recorded. Plants with purple flowers were eliminated from the row as they were encountered.

Statistical analysis was conducted using SAS (SAS Institute Inc., Cary, NC, Release 8.02). For the purpose of determining differences in plant density among rows, the experimental design was treated as a randomized complete block with four replications. Correlations were conducted using Prism (Graphpad Software, Inc., San Diego CA, Version 3.02).

Received November 23, 2002; accepted February 19, 2003.

\section{REFERENCES}

Ahrent DK, Caviness CE (1994) Natural cross pollination of twelve soybean cultivars in Arkansas. Crop Sci. 34: 376-378 Caviness CE (1966) Estimates of natural cross pollination in Jackson soybeans in Arkansas. Crop Sci. 6: 211-212

Cutler GH (1934) A simple method for making soybean hybrids. J. Am. Soc. Agron. 26: 252-254

Ellstrand NC (2001) When transgenes wander, should we worry? Plant Physiol. 125: 1543-1545

Ellstrand NC, Prentice HC, Hancock JF (1999) Gene flow and introgression from domesticated plants into their wild relatives. Annu. Rev. Ecol. Syst. 30: 539-563.

Erickson EH, Berger GA, Shannon JG, Robbins JM (1978) Honey bee pollination increases soybean yields in the Mississippi Delta region of Arkansas and Missouri. J. Econ. Entomol. 71: 601-603 
Fehr WR, Caviness CE (1977) Stages of soybean development. Iowa State University, Special Report 80, Ames, IA, $12 \mathrm{p}$

Fujita R, Ohara M, Okazaki K, Shimamoto Y (1997) The extent of natural cross-pollination in wild soybean (Glycine soja). J. Heredity 88: 124-128

Garber RJ, Odland T (1926) Natural crossing in soybeans. Am. Soc. Agron. J. 18: 967-970

Gumisiriza G, Rubaihayo PR (1978) Factors that influence outcrossing in soybean. Acker-und Pflanzenbau (J. Agron Crop Sci.) 147: 129-133

Hartwig EE, Kilen TC, Young LD (1998) Registration of "Pace" soybean. Crop Sci. 38: 1399

Kopvillem HG (1960) Nectar plants for the attraction of entomophagous insects. Hort. Abst. 31: 4376

NASS (2002) United States Department of Agriculture, National Agricultural Statistics Service, Acreage Report, 28 June 2002

Reddy MSS, Ghabrial SA, Redmond CT, Dinkins RD, Collins GB (2001) Resistance to bean pod mottle virus in transgenic soybean lines expressing the capsid polyprotein. Phytopathology 91: 831-838

Rust RW, Mason CE, Erickson EH (1980) Wild bees on soybeans, Glycine max. Environ. Entomol. 9: 230-232

Shannon JG, Collins HB (2001) Registration of DP 3588 soybean. Crop Sci. 41: 592-593

Steinlage TA, Hill JH, Nutter FW (2002) Temporal and spatial spread of soybean mosaic virus (SMV) in soybeans transformed with the coat protein gene of SMV. Phytopathology 92: 478-486

Streit LG, Beach LR, Register III JC, Jung R, Fehr WR
(2001) Association of the Brazil nut protein gene and Kunitz trypsin inhibitor alleles with soybean protease inhibitor activity and agronomic traits. Crop Sci. 41: 1757-1760

Townsend JA, Thomas LA (1994) Factors which influence the Agrobacterium-mediated transformation of soybean. J. Cell. Biochem. 23rd Annual Keystone Symposia, 18A-78

Townsend JA, Thomas LA (1996) Method of Agrobacteriummediated transformation of cultured soybean cells. U.S. Patent 5563055. Date issued: 8 October 1996

Van Emden HF (1963) An observation on the effect of flowers on the activity of parasitic Hymenoptera. Entomol. Man. Mag. 98: $255-259$

Walker D, Boerma HR, All J, Parrott W (2002) Combining cry1Ac with QTL alleles from PI 229358 to improve soybean resistance to lepidopteran pests. Mol. Breeding 9: 43-51

Wang XY, Eggenberger AL, Nutter FW, Hill JH (2001) Pathogen-derived transgenic resistance to soybean mosaic virus in soybean. Mol. Breeding 8: 119-127

Weber CR, Fehr WR (1967) Effect of hybridization and thermal neutron irradiation on quantitative characters of soybeans. Crop Sci. 7: 78

Weber CR, Hanson WD (1961) Natural hybridization with and without ionizing radiation in soybeans. Crop Sci. 1: 389-392

Woodworth CM (1922) The extent of natural cross pollination in soybeans. Agron. J. 14: 278-283

Woodworth CM (1923) Inheritance of growth habit, pod color, and flower color in soybeans. J. Am. Soc. Agron. 15: 481-495

Woodworth CM (1932) Genetics and breeding in the improvement of the soybean. Illinois Agricultural Experiment Station Bulletin. 384. Univ. of Illinois, Urbana, IL
To access this journal online: www.edpsciences.org 